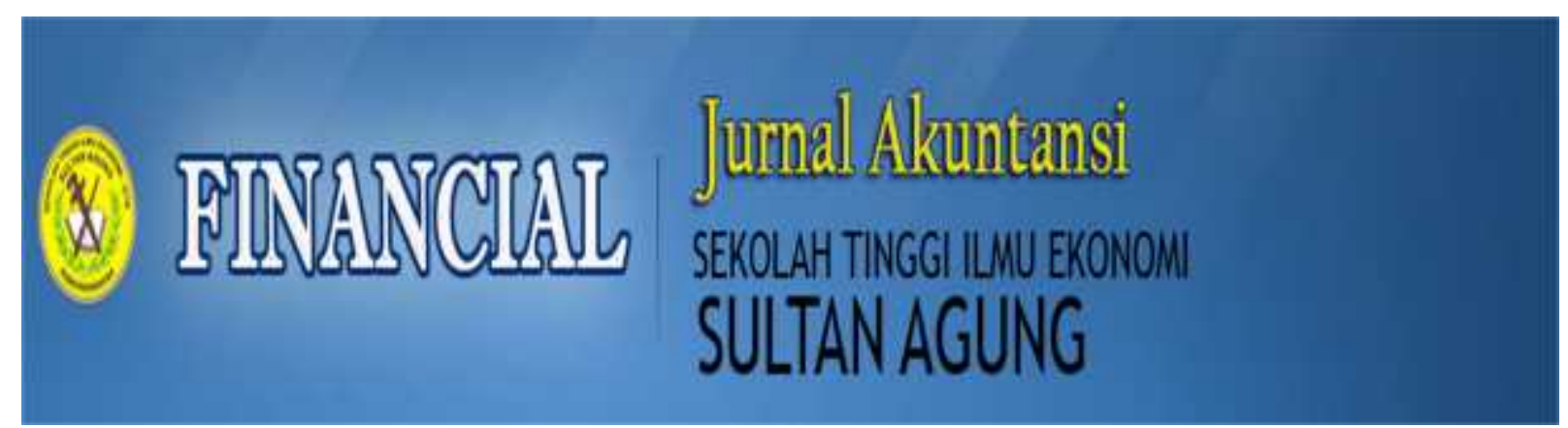

\title{
ANALISIS LIKUIDITAS, SOLVABILITAS DAN AKTIVITAS DALAM \\ MENGENDALIKAN PROFITABILITAS PADA PT INDOMOBIL SUKSES INTERNASIONAL, TbK YANG TERDAFTAR DI BURSA EFEK INDONESIA
}

\author{
Oleh : \\ Rizki Kurniawan \\ S1 Akuntansi \\ Yansen Siahaan, Ady Inrawan, Ernest Grace
}

Abstrak

Tujuan dari penelitian ini adalah untuk mengetahui gambaran likuiditas, solvabilitas, aktivitas dan profitabilitas serta faktor-faktor apakah yang menyebabkan profitabilitas PT Indomobil Sukses Internasional, Tbk yang terdaftar di Bursa Efek Indonesia cenderung menurun. Penelitian ini dilakukan dengan metode analisis deskriptif kualitatif. Pengumpulan data dilakukan dengan metode dokumentasi. Teknik analisis yang digunakan adalah analisis deskriptif kualitatif dan analisis induktif.

Hasil penelitian ini adalah Current Ratio (CR) mengalami penurunan, Debt to Asset Ratio (DAR) mengalami peningkatan, Total Asset Turn Over (TATO) mengalami penurunan dan Return on Asset (ROA) mengalami penurunan. Faktor-faktor yang menyebabkan profitabilitas menurun adalah piutang usaha, persediaan, utang usaha, utang bank jangka panjang yang segera jatuh tempo dalam waktu satu tahun, utang bank, utang obligasi dan penjualan.

Saran yang dapat diberikan adalah Sebaiknya perusahaan mengelola aset lancar dengan optimal untuk meningkatkan pendapatan, mengendalikan penggunaan utang, dan membagikan dividen kepada investor agar investor tertarik menanamkan modalnya di perusahaan.

Kata Kunci : Likuiditas, Solvabilitas, Aktivitas dan Profitabilitas

\section{Abstract}

The purpose of this research is to description of liquidity, solvability, activity and profitability and to know what factors cause the profitability of PT Indomobil Sukses Internasional, Tbk which are listed on the Indonesia Stock Exchange tend to decrease. The research was using qualitative desriptive analysis. The data collection was using documentation. The analysis techniques used are qualitative descriptive analysis methods and inductive analysis.

The result of this research are Current Ratio (CR) tends to decrease, Debt to Asset Ratio (DAR) tends to increase, Total Asset Turn Over (TATO) tends to decrease and Return on Assets (ROA) tends to decrease. The factors that cause decreased profitability are receivables, inventories, payables, longterm bank loans that are due soon, bank debt and sales.

The suggestion of this research is that it is better to issue new debt, namely long-term debt used to pay off short-term debt, consider continuing or stopping the segment of commercial vehicle sales and passengers with certain product brands that experience continuous losses, managing inventory to increase sales.

Keywords: Liquidity, Solvability, Activity and Profitability

\section{PENDAHULUAN}

\subsection{Latar Belakang Masalah}

Laporan keuangan sebagai sumber informasi keuangan utama yang disusun oleh perusahaan berdasarkan pada prinsip-prinsip akuntansi. Laporan keuangan menggambarkan kondisi perusahan sehingga memudahkan berbagai pihak yang berkepentingan dalam menilai kinerja perusahaan. Profitabilitas digunakan untuk mengukur dan menilai kemampuan perusahaan dalam memperoleh laba dengan sumber-sumber yang dimiliki perusahaan.
Profitabilitas perusahaan dapat diukur dengan Return On Asset (ROA). Rasio ini digunakan untuk mengukur seberapa besar jumlah laba bersih yang akan dihasilkan dibagi dengan total aset perusahaan. Besarnya profitabilitas yang dimiliki perusahaan dipengaruhi oleh beberapa faktor, yaitu likuiditas, solvabilitas dan aktivitas.

Likuiditas menunjukkan kemampuan perusahaan dalam membayar hutang jangka pendeknya dengan aset lancar yang dimiliki perusahaan. Likuiditas dapat diukur dengan Current Ratio (CR). Solvabilitas digunakan untuk mengukur kemampuan perusahaan 
dalam memenuhi seluruh kewajibannya, baik kewajiban jangka panjang maupun jangka pendek. Solvabilitas dapat diukur dengan Debt to Assets Ratio (DAR). Aktivitas digunakan untuk mengukur efektivitas perusahaan dalam menggunakan aset yang dimilikinya.aktivitas dapat diukur dengan Total Assets Turn Over (TATO).

Tabel 1.1

Gambaran Current Ratio, Debt to Assets Ratio Total Assets Turn Over dan Return on Assets pada PT Indomobil Sukses Internasional, Tbk yang Terdaftar di Bursa Efek Indonesia Periode 2011-2017

\begin{tabular}{|c|c|c|c|c|}
\hline \multirow{2}{*}{ Tahun } & Likuiditas & Solvabilitas & Aktivitas & Profitabilitas \\
\cline { 2 - 5 } & CR (Kali) & DAR (Kali) & $\begin{array}{c}\text { TATO } \\
\text { (Kali) }\end{array}$ & ROA (Kali) \\
\hline $\mathbf{2 0 1 1}$ & 1,368 & 0,606 & 1,222 & 0,075 \\
\hline $\mathbf{2 0 1 2}$ & 1,232 & 0,675 & 1,125 & 0,051 \\
\hline $\mathbf{2 0 1 3}$ & 1,086 & 0,702 & 0,901 & 0,028 \\
\hline $\mathbf{2 0 1 4}$ & 1,032 & 0,713 & 0,829 & $-0,003$ \\
\hline $\mathbf{2 0 1 5}$ & 0,935 & 0,731 & 0,728 & $-0,001$ \\
\hline $\mathbf{2 0 1 6}$ & 0,917 & 0,738 & 0,587 & $-0,012$ \\
\hline $\mathbf{2 0 1 7}$ & 0,838 & 0,704 & 0,490 & $-0,002$ \\
\hline
\end{tabular}

Sumber: Laporan Keuangan PT Indomobil Sukses Internasional Tbk atau Data diolah (www.idx.co.id)

Berdasarkan Tabel 1.1 di atas dapat diketahui bahwa likuiditas yang diukur dengan Current Ratio (CR) cenderung menurun pada tahun 2011-2017 diikuti dengan penurunan Return On Assets (ROA). Hal ini tidak sesuai dengan pendapat Horne dan John (2012:254), yang menyatakan bahwa likuiditas perusahaan berbanding terbalik dengan profitabilitas. Solvabilitas diukur dengan Debt to Assets Ratio (DAR) cenderung meningkat pada tahun 2011-2017 diikuti dengan penurunan Return On Assets (ROA). Hal ini tidak sesuai dengan pendapat Brigham dan Joel (2010:143), kreditor lebih menyukai rasio hutang yang rendah karena makin rendah rasio hutang, makin besar perlindungan terhadap kerugian kreditor jika terjadi likuidasi. Aktivitas yang diukur dengan Total Assets Turn Over (TATO) cenderung menurun pada tahun 2011-2017 diikuti dengan penurunan Return On Asset (ROA). Namun pada tahun 2016-2017 Total assets turn over mengalami penurunan sementara return on asset mengalami peningkatan. Hal ini tidak sesuai dengan pendapat Brigham dan Joel (2010:136), jika perusahaan memiliki terlalu banyak aset, maka biaya modalnya terlalu tinggi dan labanya akan tertekan. Dilain pihak, jika aset terlalu rendah, penjualan yang menguntungkan akan hilang.

\subsection{Rumusan Masalah}

1. Bagaimana gambaran likuiditas, solvabilitas, aktivitas, dan profitabilitas pada PT Indomobil Sukses Internasional, Tbk yang terdaftar di Bursa Efek Indonesia.

2. Faktor-faktor apakah yang menyebabkan profitabilitas PT Indomobil Sukses
Internasional, Tbk yang terdaftar di Bursa Efek Indonesia cenderung menurun.

\subsection{Tujuan Penelitian}

1. Untuk mengetahui gambaran likuiditas, solvabilitas, aktivitas dan profitabilitas pada PT Indomobil Sukses Internasional, Tbk yang terdaftar di Bursa Efek Indonesia.

2. Untuk mengetahui dan menganalisis rasio yang menyebabkan profitabilitas PT Indomobil Sukses Internasional, Tbk yang terdaftar di Bursa Efek Indonesia cenderung menurun.

\subsection{Metode Penelitian}

Penelitian ini menggunakan data sekunder dengan cara mengakses dari situs http://www.idx.co.id. Desain penelitian ini adalah penelitian kepustakaan (library research). Teknik analisa data yang digunakan adalah analisis deskriptif kualitatif dan analisis induktif.

\section{LANDASAN TEORI}

\subsection{Akuntans}

Menurut Belkaoui (2006:50), “akuntansi adalah suatu seni pencatatan, pengklasifikasian dan pengikhtisaran dalam cara signifikan dan satuan mata uang, transaksi-transaksi dan kejadian-kejadian yang paling tidak sebagian di antaranya, memiliki sifat keuangan dan selanjutnya menginterpretasikan hasilnya".

Sedangkan akuntansi menurut Niswonger et.al. (2008:7), adalah "informasi yang memberikan laporan ke pihak berkepentingan. Misalnya mengenai kegiatan ekonomi dan kondisi perusahaan". Selain itu menurut Soemarso (2009:3), "akuntansi adalah proses identifikasi, mengukur dan melaporkan informasi ekonomi untuk memungkinkan adanya penilaian yang menggunakan informasi tersebut".

\subsection{Tujuan Akuntansi}

Menurut Soemarso (2009:8), tujuan utama akuntansi adalah menyajikan informasi ekonomi (economic information) dari suatu kesatuan ekonomi (economic entity) kepada pihak-pihak yang berkepentingan.

Sedangkan menurut Harahap (2011:122), tujuan akuntansi sebagai berikut:

1. Sebagai keputusan yang menyangkut penggunaan kekayaan yang terbatas dan untuk menetapkan tujuan.

2. Mengarahkan dan mengontrol secara efektif sumber daya manusia dan faktor produksi lainnya.

3. Memelihara dan melaporkan pengumuman terhadap kekayaan.

4. Membantu fungsi dan pengawasan sosial.

\subsection{Analisa Laporan Keuangan}

Menurut Sudana (2011:20), "analisa laporan keuangan merupakan salah satu cara untuk memperoleh informasi yang bermanfaat 
dari laporan keuangan perusahaan". Sedangkan menurut Astuti (2004:29), "analisa laporan keuangan adalah adalah segala sesuatu yang menyangkut penggunaan informasi akuntansi untuk membuat keputusan bisnis dan investasi”.

Selain itu, analisa laporan keuangan menurut Munawir (2004:31), yaitu "alat yang sangat penting untuk memperoleh informasi. Sehubungan dengan posisi keuangan, dan hasil-hasil yang dicapai oleh perusahaan yang bersangkutan".

\subsection{Likuiditas}

Menurut Hery (2017:284), "likuiditas adalah rasio yang menunjukkan kemampuan perusahaan dalam memenuhi kewajiban atau membayar utang jangka pendeknya".

Menurut Brigham dan Joel (2010:134)," likuiditas adalah rasio yang menunjukkan hubungan antara kas dan aset lancar perusahaan lainnya dengan kewajiban lancarnya". Sedangkan menurut Kasmir (2015:129), "likuiditas merupakan rasio yang menggambarkan kemampuan perusahaan dalam memenuhi kewajiban (utang) jangka pendek".

\subsection{Solvabilitas}

Menurut Kasmir (2015:151), "solvabilitas adalah rasio yang digunakan untuk mengukur sampai sejauh mana aktiva perusahaan dibiayai oleh utangnya". Sedangkan menurut Sudana (2011:20), "leverage mengukur seberapa besar penggunaan utang dalam pembelanjaan perusahaan".

Selain itu menurut Hery (2017:295), "solvabilitas atau leverage merupakan rasio yang digunakan untuk mengukur kemampuan perusahaan dalam memenuhi seluruh kewajibannya, baik kewajiban jangka pendek maupun kewajiban jangka panjang".

\subsection{Aktivitas}

Menurut Astuti (2004:32), "rasio aktivitas menunjukkan seberapa cepat aset lancar dapat dikonversikan kedalam kas". Sedangkan menurut Kasmir (2015:172), "rasio aktivitas merupakan rasio yang digunakan untuk mengukur efektivitas perusahaan dalam menggunakan aktiva yang dimilikinya".

Selain itu menurut Horne dan John (2012:172), "rasio aktivitas juga disebut sebagai rasio efisiensi atau perputaran, mengukur seberapa efektif perusahaan menggunakan berbagai asetnya".

\subsection{Profitabilitas}

Menurut Brigham dan Joel (2010:122), "profitabilitas adalah sekelompok rasio yang menunjukkan kombinasi dari pengaruh likuiditas, manajemen aset dan hutang pada hasil operasi".

Sedangkan menurut Kasmir (2015:196), "profitabilitas adalah rasio yang digunakan untuk menilai kemampuan perusahaan dalam mencari keuntungan". Menurut Hery (2017:312), "profitabilitas merupakan rasio yang digunakan untuk mengukur kemampuan perusahaan dalam menghasilkan laba dari aktivitas normal bisnisnya".

\subsection{Hubungan Likuiditas, Solvabilitas} dan Aktivitas dengan Profitabilitas

Profitabilitas digunakan untuk mengukur dan menilai kemampuan perusahaan dalam memperoleh laba dengan sumber-sumber yang dimiliki perusahaan. Return on asset (ROA) sebagai proksi dalam penelitian yang digunakan untuk mengukur seberapa besar jumlah laba bersih yang akan dihasilkan dibagi dengan total aset perusahaan. Menurut Brigham dan Joel (2010:89), profitabilitas menunjukkan pengaruh gabungan dari likuiditas, manajemen aktiva dan utang terhadap operasi.

Likuiditas merupakan seberapa kemampuan perusahaan dalam melunasi liabilitas jangka pendeknya dengan menggunakan aset lancar. Perusahaan yang memiliki tingkat likuiditas tinggi terhindar dari resiko kegagalan melunasi liabilitas jangka pendeknya. Menurut Horne dan John (2012:254), likuiditas perusahaan berbanding terbalik dengan profitabilitas. Dengan kata lain, semakin tinggi likuiditas perusahaan maka kemampuan perusahaan untuk menghasilkan laba semakin rendah.

Solvabilitas digunakan untuk mengukur kemampuan perusahaan dalam memenuhi seluruh kewajiban. Menurut Brigham dan Joel (2010:143), kreditor lebih menyukai rasio hutang yang rendah karena makin rendah rasio hutang, makin besar perlindungan terhadap kerugian kreditor jika terjadi likuidasi. $\mathrm{Di}$ sisi lain, pemegang saham mungkin menginginkan lebih banyak solvabilitas karena akan memperbesar laba yang diharapkan.

Aktivitas digunakan untuk mengukur efektivitas perusahaan dalam menggunakan aset yang dimilikinya. Menurut Brigham dan Joel (2010:136), jika perusahaan memiliki terlalu banyak aset, maka biaya modalnya terlalu tinggi dan labanya akan tertekan. Dilain pihak, jika aset terlalu rendah, penjualan yang menguntungkan akan hilang. Dengan kata lain rasio aktivitas akan meningkatkan profitabilitas yang diperoleh perusahaan.

\section{PEMBAHASAN}

3.1. Analisis

3.1.1. Gambaran Likuiditas Pada PT Indomobil Sukses Internasional, Tbk yang Terdaftar di Bursa Efek Indonesia Tahun 2011-2017

Berikut ini gambaran current ratio (CR) pada PT Indomobil Sukses Internasional, Tbk yang terdaftar di Bursa Efek Indonesia Tahun 2011-2017 disajikan pada Tabel 3.1.

Tabel 3.1 
Gambaran Current Ratio (CR) pada PT Indomobil Sukses Internasional, Tbk yang terdaftar di Bursa Efek Indonesia Tahun 2011-2017

\begin{tabular}{|c|c|c|c|}
\hline Tahun & Aset Lancar (Rp) & $\begin{array}{c}\text { Kewajiban Lancar } \\
\text { (Rp) }\end{array}$ & $\begin{array}{c}\text { CR } \\
\text { (Kali) }\end{array}$ \\
\hline $\mathbf{2 0 1 1}$ & 7.405 .638 .601 .708 & 5.414 .351 .268 .862 & $\mathbf{1 , 3 6 8}$ \\
\hline $\mathbf{2 0 1 2}$ & 9.813 .158 .956 .054 & 7.963 .486 .975 .807 & $\mathbf{1 , 2 3 2}$ \\
\hline $\mathbf{2 0 1 3}$ & 11.634 .955 .170 .257 & 10.717 .554 .588 .021 & $\mathbf{1 , 0 8 6}$ \\
\hline $\mathbf{2 0 1 4}$ & 11.845 .370 .194 .860 & 11.473 .255 .532 .702 & $\mathbf{1 , 0 3 2}$ \\
\hline $\mathbf{2 0 1 5}$ & 12.192 .274 .613 .320 & 13.035 .531 .353 .729 & $\mathbf{0 , 9 3 5}$ \\
\hline $\mathbf{2 0 1 6}$ & 11.639 .697 .824 .750 & 12.594 .693 .691 .894 & $\mathbf{0 , 9 2 4}$ \\
\hline $\mathbf{2 0 1 7}$ & 13.207 .228 .569 .571 & 15.765 .338 .395 .006 & $\mathbf{0 , 8 3 8}$ \\
\hline \multicolumn{3}{|c|}{ Nilai Minimum } & $\mathbf{0 , 8 3 8}$ \\
\hline \multicolumn{3}{|c|}{ Nilai Maksimum } & $\mathbf{1 , 3 6 8}$ \\
\hline Rata-rata Keseluruhan & $\mathbf{1 , 0 5 9}$ \\
\hline
\end{tabular}

Sumber : Laporan Keuangan PT Indomobil Sukses Internasional, Tbk (Data diolah)

Dari Tabel 3.1 di atas, diketahui bahwa current ratio PT Indomobil Sukses Internasional, Tbk yang terdaftar di Bursa Efek Indonesia cenderung menurun dari tahun 2011-2017, hal ini disebabkan peningkatan kewajiban lancar jauh lebih besar dari peningkatan aset lancar. Peningkatan kewajiban lancar dapat dilihat dari utang usaha dan utang bank jangka panjang yang segera jatuh tempo dalam waktu satu tahun.

3.1.2. Gambaran Solvabilitas Pada PT Indomobil Sukses Internasional, Tbk yang Terdaftar di Bursa Efek Indonesia Tahun 2011-2017

Berikut ini gambaran solvabilitas pada PT Indomobil Sukses Internasional, Tbk yang terdaftar di Bursa Efek Indonesia Tahun 20112017 disajikan dalam Tabel 3.2.

Tabel 3.2

Gambaran DAR pada PT Indomobil Sukses Internasional, Tbk yang terdaftar di Bursa

Efek Indonesia Tahun 2011-2017

\begin{tabular}{|c|c|c|c|}
\hline \\
\hline Tahun & Total Utang (Rp) & Total Aset (Rp) & $\begin{array}{l}\text { DAR } \\
\text { (Kali) }\end{array}$ \\
\hline 2011 & 7.829 .760 .170 .144 & 12.913 .941 .646 .042 & 0,606 \\
\hline 2012 & 11.869 .218 .951 .856 & 17.577 .664 .024 .361 & 0,675 \\
\hline 2013 & 15.655 .152 .396 .933 & 22.315 .022 .507 .630 & 0,702 \\
\hline 2014 & 16.744 .375 .200 .010 & 23.471 .397 .834 .920 & 0,713 \\
\hline 2015 & 18.163 .865 .982 .392 & 24.860 .957 .839 .497 & 0,731 \\
\hline 2016 & 18.923.523.905.726 & 25.633.342.258.679 & 0,738 \\
\hline 2017 & 22.094 .058 .955 .142 & 31.375 .311 .299 .854 & 0,704 \\
\hline \multicolumn{3}{|c|}{ Nilai Minimum } & 0,606 \\
\hline \multicolumn{3}{|c|}{ Nilai Maksimum } & 0,738 \\
\hline \multicolumn{3}{|c|}{ Rata-rata Keseluruhan } & 0,696 \\
\hline
\end{tabular}

Sumber : Laporan Keuangan PT Indomobil Sukses Internasional, Tbk (Data diolah)

Dari Tabel 3.2 di atas, diketahui bahwa debt to assets ratio PT Indomobil Sukses Internasional, Tbk yang terdaftar di Bursa Efek Indonesia cenderung meningkat dari tahun 2011-2017. Hal ini disebabkan peningkatan total utang jauh lebih besar dari peningkatan total aset. Peningkatan total utang dapat dilihat dari utang bank dan utang obligasi.

3.1.3. Gambaran Aktivitas Pada PT

Indomobil Sukses Internasional, Tbk yang Terdaftar di Bursa Efek Indonesia Tahun 2011-2017

Berikut ini gambaran aktivitas pada PT Indomobil Sukses Internasional, Tbk yang terdaftar di Bursa Efek Indonesia Tahun 20112017 disajikan dalam Tabel 3.3.
Tabel 3.3

Gambaran TATO pada PT Indomobil Sukses Internasional, Tbk yang terdaftar di Bursa

Efek Indonesia Tahun 2011-2017

\begin{tabular}{|c|c|c|c|}
\hline Tahun & Penjualan (Rp) & Total Aset (Rp) & $\begin{array}{l}\text { TATO } \\
\text { (Kali) }\end{array}$ \\
\hline 2011 & 15.776 .580 .286 .659 & 12.913 .941 .646 .042 & 1,222 \\
\hline 2012 & 19.780 .838 .058 .900 & 17.577 .664 .024 .361 & 1,125 \\
\hline 2013 & 20.094 .736 .395 .135 & 22.315 .022 .507 .630 & 0,901 \\
\hline 2014 & 19.458.165.173.088 & 23.471 .397 .834 .920 & 0,829 \\
\hline 2015 & 18.099 .979 .783 .215 & 24.860 .957 .839 .497 & 0,728 \\
\hline 2016 & 15.049 .532 .331 .662 & 25.633.342.258.679 & 0,587 \\
\hline 2017 & 15.359 .437 .288 .255 & 31.375 .311 .299 .854 & 0,490 \\
\hline \multicolumn{3}{|c|}{ Nilai Minimum } & 0,490 \\
\hline \multicolumn{3}{|c|}{ Nilai Maksimum } & 1,222 \\
\hline \multicolumn{3}{|c|}{ Rata-rata Keseluruhan } & 0,840 \\
\hline
\end{tabular}

Sumber : Laporan Keuangan PT Indomobil Sukses Internasional, Tbk (Data diolah)

Dari Tabel 3.3 di atas, diketahui bahwa total asset turn over PT Indomobil Sukses Internasional, Tbk yang terdaftar di Bursa Efek Indonesia cenderung menurun dari tahun 2011-2017. Hal ini disebabkan karena penjualan mengalami penurunan sedangkan total aset meningkat. Kenaikan total aset dapat dilihat dari piutang usaha dan persediaan yang meningkat.

3.1.4. Gambaran Profitabilitas Pada PT Indomobil Sukses Internasional, Tbk yang Terdaftar di Bursa Efek Indonesia Tahun 2011-2017

Berikut ini gambaran profitabilitas pada PT Indomobil Sukses Internasional, Tbk yang terdaftar di Bursa Efek Indonesia Tahun 20112017 disajikan pada Tabel 3.4

$$
\text { Tabel } 3.4
$$

Gambaran ROA pada PT Indomobil Sukses

Internasional, Tbk yang terdaftar di Bursa Efek Indonesia Tahun 2011-2017

\begin{tabular}{|c|c|c|c|}
\hline \multirow{2}{*}{ Tahun } & & \multirow[b]{2}{*}{$\begin{array}{l}\text { ROA } \\
\text { (Kali) }\end{array}$} \\
\hline & $\begin{array}{l}\text { Laba Bersih } \\
\text { Setelah Pajak (Rp) }\end{array}$ & Total Aset (Rp) & \\
\hline 2011 & 970.891 .331 .743 & 12.913 .941 .646 .042 & 0,075 \\
\hline 2012 & 899.090 .885 .530 & 17.577 .664 .024 .361 & 0,051 \\
\hline 2013 & 621.139 .761 .829 & 22.315 .022 .507 .630 & 0,028 \\
\hline 2014 & $(67.093 .347 .900)$ & 23.471 .397 .834 .920 & $-0,003$ \\
\hline 2015 & $(22.489 .430 .531)$ & 24.860 .957 .839 .497 & $-0,001$ \\
\hline 2016 & (312.881.005.784) & 25.633 .342 .258 .679 & $-0,012$ \\
\hline 2017 & $(64.296 .811 .100)$ & 31.375 .311 .299 .854 & $-0,002$ \\
\hline \multicolumn{3}{|c|}{ Nilai Minimum } & $-0,012$ \\
\hline \multicolumn{3}{|c|}{ Nilai Maksimum } & 0,075 \\
\hline \multicolumn{3}{|c|}{ Rata-rata Keseluruhan } & 0,019 \\
\hline
\end{tabular}

Sumber : Laporan Keuangan PT Indomobil Sukses Internasional, Tbk (Data diolah)

Dari Tabel 3.4 di atas, diketahui bahwa return on asset PT Indomobil Sukses Internasional, Tbk yang terdaftar di Bursa Efek Indonesia cenderung menurun dari tahun 2011-2017. Hal ini disebabkan karena laba perusahaan mengalami penurunan sedangkan total aset perusahaan meningkat.

3.1.5. Analisis Likuiditas, Solvabilitas dan Aktivitas Dalam Mengendalikan Profitabilitas pada PT Indomobil Sukses Internasional, Tbk yang Terdaftar di Bursa Efek Indonesia Tahun 2011-2017

Dari hasil analisis diketahui bahwa faktor likuiditas yang menyebabkan profitabilitas menurun adalah utang usaha dan utang jangka 
panjang yang segera jatuh tempo dalam waktu satu tahun. Faktor solvablitas yang menyebabkan profitabilitas menurun adalah utang bank dan utang obligasi. Sedangkan faktor aktivitas yang menyebabkan profitabilitas menurun adalah penjualan, piutang usaha dan persediaan.

Berdasarkan uraian diatas dapat disimpulkan bahwa faktor-faktor yang menyebakan profitabilitas cenderung menurun adalah faktor piutang usaha, persediaan, utang usaha, utang bank jangka panjang yang segera jatuh tempo dalam satu tahun, utang bank, utang obligasi dan penjualan.

\subsection{Evaluasi}

\subsubsection{Evaluasi Likuiditas Pada PT Indomobil Sukses Internasional, Tbk yang Terdaftar di Bursa Efek Indonesia Tahun 2011-2017}

Berdasarkan hasil analisis, likuiditas pada PT Indomobil Sukses Internasional, Tbk yang terdaftar di Bursa Efek Indonesia pada tahun 2011-2017 cenderung menurun. Hal ini disebabkan oleh peningkatan utang usaha dan utang bank yang segera jatuh tempo dalam waktu satu tahun.

Nilai minimum current ratio sebesar 0,838 kali pada tahun 2017. Hal ini dikarenakan peningkatan kewajiban lancar dari tahun sebelumnya dilihat dari utang usaha dan utang bank yang segera jatuh tempo dalam waktu satu tahun. Dapat dikatakan bahwa likuditas menurun karena aset lancar yang dimiliki perusahaan tidak mampu memenuhi kewajiban lancarnya.

Untuk meningkatkan tingkat likuiditas perusahaan dapat dilakukan dengan cara menerbitkan hutang baru yakni hutang jangka panjang yang digunakan untuk melunasi hutang jangka pendeknya.

\subsubsection{Evaluasi Solvabilitas Pada PT}

Indomobil Sukses Internasional, Tbk yang Terdaftar di Bursa Efek Indonesia Tahun 2011-2017

Dari hasil penelitian, solvabilitas pada PT Indomobil Sukses Internasional, Tbk yang terdaftar di Bursa Efek Indonesia pada tahun 2011-2017 cenderung meningkat. Hal ini disebabkan oleh peningkatan total utang jauh lebih besar dari peningkatan total aset. Peningkatan total utang dapat dilihat dari utang bank dan utang obligasi.

Nilai minimum debt to assets ratio sebesar 0,606 kali pada tahun 2011. Hal ini dikarenakan jumlah total aset jauh lebih besar dari jumlah total utang perusahaan. Berdasarkan hasil analisis solvabilitas, debt to assets ratio selama 6 tahun mengalami peningkatan. Hal ini dikarenakan perusahaan menggunakan utang untuk melakukan aktivitas. Solvabilitas yang tinggi diharapkan dapat meningkatkan laba, namun kaitannya dengan profitabilitas perusahaan mengalami penurunan bahkan sampai merugi. Dengan kata lain, perusahaan tidak memanfaatkan utang dalam kegiatan operasionalnya untuk meningkatkan laba.

Untuk menurunkan utang perusahaan sebaiknya perusahaan mempertimbangkan untuk melanjutkan atau menghentikan segmen penjualan kendaraan komersil dan penumpang dengan merek produk tertentu yang mengalami kerugian terus menerus..

3.2.3. Evaluasi Aktivitas Pada PT Indomobil Sukses Internasional, Tbk yang Terdaftar di Bursa Efek Indonesia Tahun 2011-2017

Dari hasil penelitian, aktivitas pada PT Indomobil Sukses Internasional, Tbk yang terdaftar di Bursa Efek Indonesia pada tahun 2011-2017 cenderung menurun. Hal ini disebabkan penjualan perusahaan mengalami penurunan sedangkan total aset meningkat. Penurunan penjualan ini terutama disebabkan oleh penurunan penjualan yang berasal dari segmen penjualan kendaraan komersil dan penumpang. Disamping itu kenaikan total aset dapat dilihat dari piutang usaha dan persediaan yang meningkat sehingga total assets turn over menurun.

Nilai minimum total assets turn over sebesar 0,490 kali pada tahun 2017. Hal ini berarti kemampuan perusahaan menghasilkan penjualan dikatakan tidak efektif. Menurunnya aktivitas disebabkan tidak efektivitasnya penggunaan aset perusahaan dalam menghasilkan penjualan. Sebaiknya perusahaan mengelola persediaan yang dimiliki untuk meningkatkan penjualan, sehingga perusahaan semakin efektif dalam melaksanakan kegiatan operasionalnya yang pada akhirnya akan meningkatkan laba perusahaan.

3.2.4. Evaluasi Profitabilitas Pada PT Indomobil Sukses Internasional, Tbk yang Terdaftar di Bursa Efek Indonesia Tahun 2011-2017

Dari hasil penelitian, profitabilitas pada PT Indomobil Sukses Internasional, Tbk yang terdaftar di Bursa Efek Indonesia pada tahun 2011-2017 cenderung menurun. Hal ini disebabkan karena laba perusahaan mengalami penurunan sedangkan total aset perusahaan meningkat. Laba perusahaan mengalami penurunan bahkan merugi disebabkan oleh penurunan laba pada salah satu entitas asosiasi. Disamping itu kenaikan persediaan akan berdampak meningkatkan beban pokok penjualan sehingga dapat menekan laba yang dihasilkan.

Nilai minimum return on assets sebesar 0,012 kali pada tahun 2016. Hasil analisis return on assets mengalami penurunan, hal ini dikarenakan peningkatan aset perusahaan 
sedangkan laba perusahaan menurun. Dapat dikatakan penurunan ini berarti kemampuan perusahaan dalam menghasilkan laba kurang baik. Hal ini karena beban operasi yang tinggi, terutama pada beban pokok penjualan sehingga menurunkan laba perusahaan. Sebaiknya perusahaan mengelola likuiditas, manajemen aset dan manajemen utang dengan baik untuk meningkatkan profitablitas perusahaan.

\section{KESIMPULAN DAN SARAN}

\subsection{Kesimpulan}

1. Tingkat likuiditas PT Indomobil Sukses Internasional, Tbk yang terdaftar di Bursa Efek Indonesia mengalami penurunan secara keseluruhan. Hal ini dikarenakan utang lancar perusahaan yang meningkat dibanding dengan aset lancar. Utang lancar meningkat terutama dari pinjaman jangka pendek dan utang usaha.

2. Tingkat solvabilitas PT Indomobil Sukses Internasional, Tbk yang terdaftar di Bursa Efek Indonesia mengalami kenaikan secara keseluruhan. Hal ini menunjukkan semakin besar penggunaan utang dalam kegiatan operasional perusahaan maka semakin besar pula resiko keuangan perusahaan apabila dibubarkan.

3. Tingkat aktivitas PT Indomobil Sukses Internasional, Tbk yang terdaftar di Bursa Efek Indonesia mengalami penurunan. Hal ini disebabkan oleh kurang efektifnya perusahaan melakukan penjualan. Dengan kata lain penjualan menurun dan relatif lebih kecil dari penambahan total aktiva.

4. Tingkat profitabilitas PT Indomobil Sukses Internasional, Tbk yang terdaftar di Bursa Efek Indonesia mengalami penurunan. Hal ini disebabkan peningkatan aset perusahaan yang lebih besar dari pada peningkatan laba perusahaan.

5. Tingkat likuiditas, solvabilitas dan aktivitas dalam mengendalikan profitabilitas, bila dilihat profitabilitas yang menurun dapat dikatakan kinerja keuangan tidak baik, hal ini disebabkan oleh faktor piutang usaha, persediaan, utang usaha, utang bank jangka panjang yang segera jatuh tempo dalam waktu satu tahun, utang bank, utang obligasi dan penjualan.

\subsection{Saran}

1. Untuk meningkatkan tingkat likuiditas perusahaan dapat dilakukan dengan cara menerbitkan hutang baru yakni hutang jangka panjang yang digunakan untuk melunasi hutang jangka pendeknya.

2. Untuk menurunkan utang perusahaan sebaiknya perusahaan mempertimbangkan untuk melanjutkan atau menghentikan segmen penjualan kendaraan komersil dan penumpang dengan merek produk tertentu yang mengalami kerugian terus menerus.

3. Sebaiknya perusahaan mengelola persediaan yang dimiliki untuk meningkatkan penjualan, sehingga perusahaan semakin efektif dalam melaksanakan kegiatan operasionalnya yang pada akhirnya akan meningkatkan laba perusahaan.

4. Sebaiknya perusahaan mengelola likuiditas, manajemen aset dan manajemen utang dengan baik untuk meningkatkan profitablitas perusahaan.

\section{DAFTAR PUSTAKA}

Astuti, Dewi. 2004. Manajemen Keuangan Perusahaan. Cetakan Pertama. Jakarta: Ghalia Indonesia.

Belkoui, Ahmed Riahi. 2006. Teori Akuntansi. Edisi V, Buku 1. Jakarta: Salemba Empat.

Brigham, Eugene F., dan Joel F. Houston. 2010. Dasar-dasar Manajemen Keuangan. Buku 1, Edisi II. Jakarta: Salemba Empat.

Harahap, Sofyan Syafri. 2011. Teori Akuntansi. Edisi Revisi. Jakarta: PT Raja Grafindo Persada.

Hery. 2017. Teori Akuntansi Pendekatan Konsep dan Analisis. Jakarta: PT Grasindo.

Horne, James C. Van dan John M. Wachowicz. 2012. Prinsip-prinsip Manajemen Keuangan. Buku 1, Edisi XIII. Jakarta: Salemba Empat.

Kasmir. 2015. Analisis Laporan Keuangan. Edisi VIII, Cetakan Kedelapan. Jakarta: Rajawali Pers.

Munawir, S. 2004. Analisa Laporan Keuangan. Yogyakarta: Liberty.

Niswonger, Rollin et. al. 2008. Prinsip-prinsip Akuntansi. Terjemahan Alfansus Sirait dan Helda Gunawan. Edisi 19. Jilid Pertama. Jakarta: Erlangga.

Soemarso, S. R. 2009. Akuntansi Suatu Pengantar, Buku 2 Edisi kelima. Jakarta: Salemba Empat.

$\begin{array}{ccc}\text { Sudana, I Made. 2011. } & \text { Manajemen } \\ \text { Keuangan } & \text { Perusahaan } \\ \text { Praktek. } & \text { Jakarta: } & \begin{array}{c}\text { teori dan } \\ \text { Erlangga. }\end{array}\end{array}$ 